\title{
Алла Балацинова
}

кандидат педагогічних наук, доцент, докторант кафедри освітології та інноваційної педагогіки Харківський національний педагогічний університет імені Г. Сковороди;

Харків, Україна

ORCID: 0000-0002-3247-0694

E-mail: balatsynova.alla@gmail.com

\section{ДОСВІД РОЗВ'ЯЗАННЯ ПРОБЛЕМИ ВІДКРИТТЯ ШЛЯХЕТНИХ ПАНСІОНІВ ПРИ ГІМНАЗІЯХ У ДІЯЛЬНОСТІ РАДИ ПРИ ПОПЕЧИТЕЛІ КИЇВСЬКОГО НАВЧАЛЬНОГО ОКРУГУ}

Анотащія: у статті на основі аналізу нормативно-правових та архівних документів розглянуто досвід розв'язання проблеми відкриття шляхетних пансіонів при гімназіях у діяльності ради при попечителі Київського навчального округу. На прикладі відкриття 2-го шляхетного пансіону при 1-й Київській гімназії (1836 р.) з'ясовано позицію ради з даного питання, порядок ухвалення і виконання ії рішень. Члени ради при попечителі Київського навчального округу після детального аналізу стану справ вже діючого шляхетного пансіону при 1-й Київській гімназії дійшли висновку про необхідність відкриття ще одного пансіону, схвалили розроблений для нього попечителем навчального округу штат, висловили пропозиції щодо джерел фінансування його початкового облаштування.

Установлено, що думка ради при попечителі Київського навчального округу щодо відкриття 2-го шляхетного пансіону при 1-й Київській гімназії була врахована Міністерством народної освіти при ухваленні остаточного рішення.

Ключові слова: Міністерство народної освіти, Київський навчальний округ, рада при попечителі навчального округу, гімназія, пансіон.

\section{Alla Balatsynova \\ candidate of pedagogical sciences, associate professor, doctoral student of the department of education and innovative pedagogy, Kharkiv National Pedagogical University named after G. Skovoroda; Kharkiv, Ukraine \\ E-mail: balatsynova.alla@gmail.com \\ PROBLEM-SOLVING EXPERIENCE WHEN OPENING NOBLE GYMNASIUMS' BOARDING HOUSES IN THE KYIV EDUCATIONAL DISCTRICT CURATOR'S COUNCIL ACTIVITIES}

Abstract: based on regulatory and archival documents analysis, the article considers the problemsolving experience when opening noble gymnasiums' boarding schools in the Kiev educational district curator's council activities. The Council's position on this issue, the procedure for making and executing its decisions are clarified on the example of opening the second boarding school at the first Kiev gymnasium in 1836. Thoroughly analysing the state of affairs of the already-performing noble boarding school at the first Kiev gymnasium, Kiev educational district curator's council members came to the conclusion that one more boarding school opening was necessary. They either approved of the staff developed by the educational district curator, and made proposals on sources of its initial arrangement funding.

It is established that the opinion of Kiev educational district curator's council regarding the second noble boarding school opening at the first Kyiv gymnasium was taken into account by the Ministry of public education when making the final decision.

Key words: Ministry of public education, Kyiv educational district, Curator's council of the educational district, gymnasium, boarding school. 


\title{
Алла Балацинова
}

\section{ОПЫТ РЕШЕНИЯ ПРОБЛЕМЫ ОТКРЫТИЯ БЛАГОРОДНЫХ ПАНСИОНОВ ПРИ ГИМНАЗИЯХ В ДЕЯТЕЛЬНОСТИ СОВЕТА ПРИ ПОПЕЧИТЕЛЕ КИЕВСКОГО УЧЕБНОГО ОКРУГА}

\begin{abstract}
Аннотачия: в статье на основе анализа нормативно-правовых и архивных документов рассмотрен опыт решения проблемы открытия благородных пансионов при гимназиях в деятельности совета при попечителе Киевского учебного округа. На примере открытия 2-го благородного пансиона при 1-й Киевской гимназии (1836 г.) выяснена позиция совета по данному вопросу, порядок принятия и исполнения его решений. Члены совета при попечителе Киевского учебного округа после детального анализа состояния дел уже действующего благородного пансиона при 1-й Киевской гимназии пришли к выводу о необходимости открытия еще одного пансиона, одобрили разработанный для него попечителем учебного округа штат, высказали предложения по источникам финансирования его первоначального устройства.

Установлено, что мнение совета при попечителе Киевского учебного округа по открытию 2-го благородного пансиона при 1-й Киевской гимназии было учтено Министерством народного просвещения при принятии окончательного решения.

Ключевые слова: Министерство народного образования, Киевский учебный округ, совет при попечителе учебного округа, гимназия, пансион.
\end{abstract}

\section{Alla Balatsynova}

An extended abstract of a paper on the subject of:

'Problem-solving experience when opening noble gymnasiums' boarding houses in the Kyiv educational disctrict curator's council activities"

Problem setting. In Ukraine, ensuring citizens' equal access to education is one of the priorities of the state educational policy. Implementing the Laws of Ukraine "On Education" and "On Full General Secondary Education" is aimed at completing certain tasks. In particular, the territorial accessibility of full general secondary education should be ensured by state authorities and local government bodies within their powers. One of the ways to solve this problem is to create boarding schools, namely structural divisions of educational institutions providing accommodation and maintenance for students who study there.

Taken the actuality of the above problem into account, it is expedient to address to the study, critical analysis and creative use of the experience in organizing boarding schools in the Ukrainian lands in the first half of the nineteenth century.

Recent research and publications analysis. In the scientific discourse, the outlined problem is partially covered in the context of secular education organization (V. Masliychuk), public and private secondary educational institutions opening and functioning (N. Goncharova, $O$. Druganova, etc.), and state regulation of their activities (L. Prokopenko).
As the analysis of historical and historicalpedagogical literature shows, there are no works in the current scientific space that would systematically study the issue of opening noble boarding schools in the activities of the highest collegial advisory bodies of educational districts, namely educational district curator's council.

Paper objective. The article objective is to describe the problem-solving experience of the Kiev educational district curator's council when opening noble gymnasiums' boarding schools (on the example of the second noble boarding school at the first Kiev gymnasium in 1836).

Paper main body. Similar to private closed educational institutions with dormitories and full student maintenance, boarding schools commenced to appear in the Ukrainian provinces of the Russian Empire in the second half of the nineteenth century for the nobles and wealthy merchants children. They were mostly opened by foreigners. After having introduced the new educational system at the beginning of the nineteenth century, the imperial government faced the problem when state secondary educational institutions, namely gymnasiums, were becoming rather unpopular among the nobles, who were not 
satisfied with their overseas nature and extensive training program. They preferred homeschooling and attending private boarding schools, which did not meet the interests of the state for several reasons: 1) lacking in number of qualified teachers; 2) the lack of government control over education direction; 3 ) the inability to urge youth to adjust to generally accepted social rules.

State noble boarding schools were supposed to serve as a means of forming sympathy of the nobles for gymnasiums, which gradually began opening at some gymnasiums. Some appeared to be purely educational institutions, whose pupils studied gymnasium subjects. Others, in addition to the gymnasium course, taught subjects specifically favored by the nobles, such as military sciences and "fine arts". The rest, like Moscow university noble boarding school, were completely independent educational institutions with a gymnasium course, supplemented by separate sciences and arts.

The "Charter of county and parish gymnasiums and schools of St. Petersburg, Moscow, Kazan, and Kharkiv universities" (dated 1828) determined the provision of nobles and officials living in the provinces with the means to raise their children decently at no extra cost in order to establish boarding gymnasiums' schools. They had to be opened and maintained at the expense of voluntary contributions (donations) and the set pupils maintenance fee. Pensioners were to study at gymnasiums with other students, and be under special supervision of the boarding school authorities while extracurricular activities. In 1834, a noble boarding school operated at the first Kiev educational district out of seven gymnasiums.

However, the inability to satisfy the requests of the nobles for their children to be placed in a noble boarding school at the first Kiev gymnasium forced the Kiev educational district

Постановка проблеми у загальному вигляді та її зв'язок із важливими науковими чи практичними завданнями. В Україні забезпечення рівного доступу громадян до освіти належить до пріоритетних напрямів державної освітньої політики. На реалізацію визначених завдань спрямована імплементація Законів України "Про освіту”, "Про повну загальну середню освіту". Зокрема, територіальну доступність повної загальної середньої освіти мають забезпечувати у межах своїх пов-
Curator to apply to the Minister of Public Education with a request to open a second boarding school at this gymnasium in 1835. In the response of the Minister, opening a new boarding school was considered as inconvenient and expanding the capabilities of the existing one was suggested. Though it was impossible to solve the problem in such a way, thus, the Kiev educational district curator submitted the issue of opening the second noble boarding school at the first Kiev gymnasium to be regarded by the higher collegial advisory body of the educational district, namely the curator's council. Having thoroughly considered this problem, taking into account social, financial, administrative and other factors, the council members supported the idea of opening the second noble boarding school at the first Kiev gymnasium.

Conclusions of the research. The carried out research suggests the problem of opening the second noble boarding school at the first Kiev gymnasium being under the control of the Minister of public education. The curator's council members expressed their own position on the Kiev educational district curator's suggestion. This had been preceded by thoroughly studying the already existing noble boarding school affairs at the first Kiev gymnasium.

The Council's resolution considered opening the second boarding school at the first Kiev gymnasium necessary; it either approved the staffs developed by the educational district curator, and made suggestions regarding the funding sources for the new boarding school initial arrangement.

The Kiev educational district curator's council opinion on opening the second noble boarding school at the first Kiev gymnasium and the draft of its staffs were sent to the Minister of public education and taken into account when making the final decision.

новажень органи державної влади та органи місцевого самоврядування. Одним із шляхів розв'язання даної проблеми є створення пансіонів. У Законі України "Про повну загальну середню освіту" термін "пансіон” вживається у значенні "структурний підрозділ закладу освіти, що забезпечує проживання та утримання учнів відповідно до законодавства" [9].

Умови і правила проживання та утримання учнів у пансіонах ліцеїв, закладів спеціалізованої освіти (наукових, мистецьких, 
спортивних, військових (військово-морських, військово-спортивних) ліцеїв та ліцеїв із посиленою військово-фізичною підготовкою), спеціальних закладів загальної середньої освіти (навчально-реабілітаційних центрів та спеціальних шкіл), до яких вони зараховані для здобуття загальної середньої освіти, визначено у постанові Кабінету Міністрів України від 03.11.2021 № 1131 "Про затвердження Порядку проживання та утримання учнів у пансіонах закладів освіти". У документі акцентовано увагу на тому, що утримання учнів, які проживають у пансіоні закладу освіти, передбачає забезпечення їх харчуванням, медичними та іншими послугами відповідно до законодавства [8].

Зважаючи на актуальність зазначеної вище проблеми, доцільним $є$ звернення до вивчення, критичного аналізу i творчого використання досвіду організації пансіонів в на українських землях у першій половині XIX століття.

Аналіз останніх досліджень та публікацій, у яких започатковано розв'язання цієї проблеми і на які спирається автор. У науковому дискурсі окреслена проблема знайшла часткове висвітлення в контексті організації світської освіти (В. Маслійчук [7]), відкриття та функціонування державних i приватних середніх навчальних закладів (Н. Гончарова [2], О. Друганова [3] та ін.), державного регулювання їхньої діяльності (Л. Прокопенко [10]). Кожна згадка вчено повиння закінчуватися посиланням на його роботу у списку використаних джерел

Зокрема, нНауковий інтерес у контексті досліджуваної проблеми викликає дисертація В. Маслійчука (2019), у якій на основі аналізу писемних джерел комплексно досліджено задуми та втілення ідей світських навчальних закладів на території Лівобережної та Слобідської України від початків секулярних проєктів до часу реалізації системи освіти. Узагальнюючи появу училищ та перші кроки світської освіти на цих теренах, науковець говорить про “просвітницьку ілюзію” щодо початків освітніх процесів: спроба імперії виховати освіченого “громадянина на службі держави" натрапляла на соціальні перепони й попередні освітні практики, що згодом спричинило обмеження доступу до освіти та державні спроби контролювати викладання й активність [7].

Друганова О. (2009), вивчаючи особ- ливості становлення та розвитку приватної середньої школи в Україні, дійшла висновку, що збільшення кількості приватних шкіл наприкінці XVIII - у першій третині XIX століття було зумовлено такими чинниками: небажання дворянських родин навчати своїх дітей разом із дітьми інших станів i статків; недовіра до казенних училищ i, передусім, до їхньої широкої програми навчання; низька якість організації казенних навчальних закладів. Приватні пансіони дослідниця розглядає як приватні середні навчальні заклади закритого типу, що надавали учням повне або часткове утримання, усебічну опіку, грунтовну освіту та моральне вдосконалення [3].

Дослідження Л. Прокопенка (2019) присвячене проблемі державного регулювання розвитку приватної освіти на українських теренах у першій половині XIX століття. Аналіз нормативно-правових актів, якими регламентувався порядок відкриття приватних навчальних закладів, організаціяї в них навчально-виховного процесу, надання домашньої освіти тощо, дозволив досліднику дійти висновку, що унормування їхньої діяльності приватних навчальних закладів упродовж досліджуваного періоду сприяло розвитку приватної, особливо жіночої, освіти [10].

Організаційні засади функціонування шляхетних пансіонів у південноукраїнських губерніях у першій половині XIX століття стали предметом вивчення Н. Гончарової. Особливу увагу дослідниця приділила дослідженню внутрішнього устрою, організації навчально-виховного процесу та особливостей побуту в станових навчальних закладах для дворянської молоді південноукраїнських губерній. На ii переконання, шляхетні пансіони зробили помітний внесок у виховання й освіту південноукраїнського дворянства, у формування службової та культурної еліти [2].

Виділення невирішених раніше частин загальної проблеми, котрим присвячується дана стаття. Як свідчить аналіз історичної та історико-педагогічної літератури, у науковому просторі сучасності відсутні праці, у яких би системно досліджувалося питання відкриття шляхетних пансіонів у діяльності вищих колегіальних дорадчих органів навчальних округів - рад при попечителях навчальних округів.

Формування цілей статті (постановка завдання). Мета статті - схарактеризувати 
досвід ради при попечителі Київського навчального округу 3 розв'язання проблеми відкриття шляхетних пансіонів при гімназіях (на прикладі 2-го шляхетного пансіону при 1й Київській гімназії у 1836 році).

Виклад основного матеріалу дослідження 3 повним обгрунтуванням отриманих наукових результатів. В Україні приватні пансіони - закриті навчальні заклади з гуртожитком і повним утриманням учнів - почали 3'являтися у другій половині XVIII століття. Вони відкривалися переважно іноземцями (французами та німцями) і були розраховані на дітей дворянства і заможного купецтва. Предметами навчання у них були насамперед іноземні мови, література, музика, спів, малярство, танець. Особлива увага в цих пансіонах приділялася вихованню світських манер [1].

У процесіПід час освітньої реформи 1802-1804 років в у Російській імперії була запроваджена нова система освіти, яка передбачала функціонування чотирьох типів навчальних закладів - парафіяльні, повітові училища, губернські училища або гімназії та університети [15]. "Статут навчальних закладів, підпорядкованих університетам”, затверджений 05 листопада 1804 року, визначив завдання гімназій, повітових i парафіяльних училищ, вимоги до їхніх штатів, навчальних планів, викладання навчальних предметів, навчальних посібників, окреслив обов'язки вчителів, учнів i керівництва цих закладів. Окремий розділ Статуту було присвячено приватним пансіонам. У ньому було визначено порядок відкриття пансіонів та організації в них навчально-виховного процесу, права й обов'язки їхніх власників i вчителів тощо. Зокрема, відкрити приватний пансіон міг будь-хто, хто мав відповідний освітній ценз. Дозвіл на відкриття пансіону надавав університет. Він же затверджував його навчальний план. Утримувач пансіону не обмежувався у виборі предметів для викладання, але пансіонери обов'язково мали вивчати російську мову і Закон Божий. Контроль за діяльністю приватних пансіонів покладався на директорів гімназій [13].

Проте 3 самого початку функціонування нової шкільної системи стало зрозумілим, що казенні навчальні заклади мало задовольняють потреби тих станів суспільства, для яких вони призначалися. Про це свідчила, зокрема, досить мала кількість учнів у гімназіях і повітових училищах по на всій території державіи. В українських губерніях багаті дворяни, яких не влаштовував загальностановий характер гімназій, віддавали перевагу домашнім учителям і приватним пансіонам, що утримувалися переважно іноземцями [12, c. 69]. Разом 3 тим, на переконання М. Сперанського, як домашне навчання, так i навчання в приватних пансіонах, зумовлювало низку утруднень для держави через брак достатньої кількості кваліфікованих учителів, через відсутність засобів контролю з боку уряду за спрямованістю виховання дворянських дітей, а також неможливістю привчання юнацтва до єдиних суспільних правил [6].

Засобом формування симпатій дворянства до гімназій мали служити казенні шляхетні пансіони, що поступово стали відкриватися при деяких гімназіях. Одні з них були суто виховними закладами, вихованці яких вивчали навчальні предмети у гімназіях. В інших на додаток до гімназичного курсу викладалися предмети, які особливо поціновувалися дворянами: воєнні науки i "приємні мистецтва". Треті, на зразок Московського університетського шляхетного пансіону, були абсолютно самостійними навчально-виховними закладами 3 гімназичним курсом, що доповнювався окремими науками і мистецтвами, зокрема, тими, що вимагалися для складання екзамену згідно з указом від 06 серпня 1809 року "Про правила надання чинів по цивільній службі й про випробування в науках для призначення в колезькі асесори і статські радники" $[12$, с. 70$]$. Водночас, під впливом національного піднесення напередодні Франкоросійської війни Міністерство народної освіти у 1811 році порушує питання про негативний вплив іноземних вихователів i вживає обмежувальних заходів проти приватних пансіонів [12, с. 76].

Питання про статус шляхетних пансіонів порушувалося і в наступні роки. У 1818 році Учений комітет Міністерства духовних справ і народної освіти висловив думку, що пансіони $\epsilon$ такими навчальними закладами, у яких утримання й безперервний нагляд поєднуються 3 викладанням навчальних предметів. Проте Головне правління училищ дотримувалося іншої позиції. 30 січня 1819 року воно затвердило положення, згідно 3 яким пансіони при гімназіях та університетах вважалися виключно місцями, що призначені для утримання 
юнацтва, яке навчається. Навчатися ж пансіонери мали разом із іншими в гімназіях та університетах. Винятки 3 цього правила були можливими за умови, що вони не порушують загального порядку в системі гімназичного навчання, і тільки 3 дозволу міністра. Винятки склали шляхетні пансіони при СанктПетербурзькому і Московському університетах й Вище училище, що було відкрите на базі пансіону Санкт-Петербурзької гімназії [12, с. 139].

У новому "Статуті гімназій і училищ повітових та парафіяльних, що перебувають у відомстві університетів: Санкт-Петербурзького, Московського, Казанського і Харківського", затвердженому 08 грудня 1828 року, метою засновування при гімназіях пансіонів було визначено надання дворянам і чиновникам, які проживали в губерніях, засобів пристойно виховувати своїх дітей без зайвих на те витрат. Відкриватися й утримуватися вони мали за рахунок добровільних внесків (пожертв) i встановленої за утримання вихованців плати. Пансіонери мали навчатися в гімназіях разом із іншими учнями, а в позаурочний час перебувати під особливим наглядом начальства пансіонів [14]. Таким чином, згідно зі Статутом 1828 року гімназичні пансіони були тільки виховними закладами.

Проте керуючий Міністерством народної освіти С. Уваров, який був прихиль-ником станового розмежування загальної освіти, поділяючи думку про необхідність для дворян спеціальних освіти і виховання, циркуляром від 16 травня 1833 року закріпив за шляхетними пансіонами інший статус: як самостійних навчальних закладів для підготовки юнаків до отримання освіти в університетах [4].

Водночас, кількість шляхетних пансіонів в українських губерніях Російської імперії лишалася незначною. Так, у 1834 році в Київському навчальному окрузі, до якого входило 4 губернії (Київська, Чернігівська, Волинська, Подільська), із 7 гімназій лише при одній функціонував пансіон [5, с. 85-86]. Це був шляхетний пансіон при Київській гімназії, відкритий 19 серпня 1834 року. У пансіоні перебували 41 своєкоштний пансіонер i 20 вихованців, які утримувалися за рахунок Державного казначейства з розрахунку 500 руб. на кожного в рік упродовж семирічного курсу 3 тим, аби вони переходили 3 гімназії до університету Св. Володимира для підготовки до вчительського звання. Разом із тим площа будинку, який було орендовано під пансіон, не дозволила задовольнити бажання більше, аніж 20-ти батьків щодо розміщення їхніх дітей у цьому закладі [5, с. 90-91].

05 вересня 1836 року попечитель Київського навчального округу Є. фон Брадке звернувся до міністра народної освіти із клопотанням за № 4073 про відкриття при 1-й Київській гімназії 2-го шляхетного пансіону. Він зауважував, що кількість учнів у закладах освіти округу так стрімко зростає, що ті посилені заходи, які вживаються для збільшення способів виховання юнацтва, ледве встигають задовольняти місцеві потреби. Яскравим прикладом ситуації, що склалася, попечитель назвав пансіон при 1-й Київській гімназії, чисельність вихованців якого впродовж короткого терміну зросла до 121 особи. На переконання попечителя, цей факт свідчив про те, що місцеве дворянство мало велику потребу у відкритті цього закладу. Водночас, були ще бажаючі віддати до шляхетного пансіону своїх дітей та родичів. Проте через відсутність вакансій, тісноту будинку, який займав пансіон, не було жодної можливості збільшити кількість пансіонерів. 3 огляду на обставини, що склалися, С. фон Брадке вважав за потрібне відкрити при 1-й Київській гімназії 2-й шляхетний пансіон. Це питання він виніс на обговорення ради при попечителі - колегіального дорадчого органу Київського навчального округу [11, арк. 1].

На засіданні ради попечитель навчального округу довів до відома іiі членів як пропозиції, що були ним висловлені в поданнях міністру народної освіти від 05 вересня та 12 жовтня 1835 року за № 1571 і № 1862, так і відповідь міністра народної освіти від 31 жовтня того ж року за № 11619 [11, арк. 1 зв.]. Зокрема, в С. фон Брадке повідомив, що міністр народної освіти вважає відкриття другого шляхетного пансіону при 1й Київській гімназії незручним із декількох причин: по-перше, подвоєння господарства призведе до зростання витрат і збільшення турбот; по-друге, нагляд за двома закладами буде досить обтяжливим для директора та інспектора гімназії. Водночас виплата жалування спеціальному наглядачеві, посада якого не була передбачена статутом, виявиться тягарем для пансіону. Тому, на переконання міністра, збільшення кількості кімнатних наглядачів і служителів, навчальних посіб- 
ників та інших речей у пансіоні, який вже існував, а також надання йому помешкання більшої площі $є$ незрівнянно кориснішим i більше відповідає меті, ніж заснування нового пансіону [11, арк. 2 зв.-3].

Оскільки 3 пошуком більшого будинку виникли труднощі, попечитель Київського навчального округу з дозволу міністра народної освіти звернувся до Київського губернського предводителя дворянства по допомогу на облаштування будинку для пансіону, але не отримав задовільної відповіді. Пізніше було укладено контракт із графом Ілінським про оренду його будинку на 5 років для шляхетного пансіону 1-ої Київської гімназії, у якому могли розміститися 120 вихованців. Новий штат для розширеного пансіону було затверджено міністром народної освіти 17 червня і введено в дію 02 липня 1836 року [11, арк. 3 зв.]. Але цього виявилося недостатньо для задоволення місцевих потреб, оскільки тіснота приміщення перешкоджала зарахуванню більшого числа вихованців.

Ухвалюючи своє рішення, рада при попечителі Київського навчального округу взяла до уваги ці обставини, а також наступне:

1) у Києві немає жодного будинку, більшого за будинок графа Ілінського, а отже немає можливості розширити діючий пансіон;

2) будівництво нового будинку може тривати довгий час через відсутність джерел фінансування i навіть за їх наявності будівництво такого великого приміщення триватиме не менше 3-х років;

3) збільшення кількості місць $у$ пансіоні більше ніж на 30 цього року не змогло задовольнити потреби краю. Наступного року, коли з'явиться лише одна вакансія після закінчення курсу гімназичного навчання одним своєкоштним пансіонером, виховання юнацтва зустрінеться 3 великими перешкодами через ненадання батькам способів розміщення їхніх дітей;

4) хоча подвоєння господарства і має свої незручності, проте різниця у витратах порівняно 3 більшими закладами навряд чи буде суттєвою;

5) на інспектора гімназії покладання обов’язків по щодо другому другого пансіону не видається доцільним - завідування ним можна доручити спеціальному наглядачеві. Роботи у директора гімназії із відкриттям другого пансіону хоча і додаєсться, але рада таке збільшення його обов'язків не вважає обтяжливим, оскільки за потреби має зменшитися кількість вільноприходящих учнів;

6) сума витрат нового пансіону на жалування спеціальному наглядачеві не збільшиться, оскільки йому має бути призначена така сама сума жалування, яку б отримували директор та інспектор гімназії як додатковий оклад при збільшенні штату діючого пансіону на 60 вихованців [11, арк. 3 зв.].

Зважаючи на вищезазначене, рада визнала відкриття 2-го пансіону при 1-й Київській гімназії корисним і навіть необхідним, а розроблений попечителем навчального округу для нього штат зручним. Що стосується коштів, необхідних для початкового облаштування нового пансіону, було запропоновано запозичити 11 тис. руб. асигнаціями із сум діючого першого пансіону (на рахунок внесків вихованців при їх вступі по 200 руб. асигнаціями на початкове облаштування) 3 виплатою цієї суми впродовж 3 років [11, арк. 4-5 зв.].

Висновки ради та проєкт штату 2-го шляхетного пансіону при 1-й Київській гімназії попечитель Київського навчального округу додав до клопотання про відкриття даного закладу, що було надіслане міністру народної освіти [11, арк. 6-6 зв.]. Штат другого шляхетного пансіону було укладено з розрахунку на 60 вихованців з урахуванням того, що кожен із них щорічно буде сплачувати внесок у розмірі 800 руб. асигнаціями. Загальні витрати на його утримання складали 46250 руб. асигнаціями [11, арк. 11].

Аналіз архівних документів [11] засвідчив той факт, що указом від 19 вересня 1836 року при 1-й Київській гімназії було відкрито 2-й шляхетний пансіон, де могло перебувати одночасно 60 вихованців. Для безпосереднього завідування пансіоном під керівництвом директора гімназії було призначено спеціального інспектора 3 жалуванням із сум пансіону з правами інспектора гімназії.

Висновки 3 даного дослідження та перспективи подальших розвідок у даному напрямку. Проведене дослідження дає підстави свідчити, що проблема відкриття 2-го шляхетного пансіону при 1-й Київській гімназії перебувала під контролем міністра народної освіти. На пропозицію попечителя Київського навчального округу члени вищого колегіального дорадчого органу навчального округу ради при попечителі - висловили власну пози- 
цію 3 даного питання. Цьому передувало детальне вивчення стану справ вже діючого шляхетного пансіону при 1-й Київській гімназії.

В ухвалі ради відкриття 2-го пансіону при 1-й Київській гімназії було визнано необхідним, схвалено розроблений попечителем навчального округу для нього штат, а також висловлено пропозиції щодо джерел фінансування початкового облаштування нового пансіону.

Думка ради при попечителі Київського

\section{Список літератури:}

1. Гончаренко С. У. Український педагогічний словник / С. У. Гончаренко. - Київ: Либідь. -, 1997. - С. 247.

2. Гончарова Н. Організаційні засади функціонування шляхетних пансіонів у південноукраїнських губерніях у першій половині ХІХ століття / Н. Гончарова // Наукові записки Національного університету “Острозька академія". - Серія : Історичні науки. - 2014. - Вип. 22. - С. 88-97

3. Друганова О. М. Становлення та розвиток приватної середньої школи в Україні (кінець XVIII - перша половина XIX століття) / О. М. Друганова // Дриновський збірник. Софія; Харків, 2018. - Т. 11. - С. 79-88

4. Журнал Министерства народного просвещения. - 1834. - Ч. 1. - Отд. І. - С. 53-59

5. Журнал Министерства народного просвещения. - 1835. - Ч. 6. Отд. І. - С. 85-86, 90-91.

6. Записка графа Сперанского “Об усовершении общего народного воспитания" // Русская старина. - 1907. - Т. 132. - С. 731

7. Маслійчук В. Л. Культурно-освітні ініціативи на Лівобережній та Слобідській Україні другої половини XVIII - початку XIX ст. / В. Л. Маслійчук //: Автореф.дис....д-ра іст. наук : 07.00.01. - Запоріжжя. - 2019. - С. 34

8. Про затвердження Порядку проживання та утримання учнів у пансіонах закладів освіти [електронний ресурс] //: Постанова Кабінету Міністрів України від 03.11.2021 № 1131. - Режим доступу: https:/www.kmu.gov.ua/npas/pro-zatverdzhenn ya-poryadku-prozhivannya-ta-utrimannya-uchniv -s1131-31121 (дата звернення: 04.11.2021)

9. Про повну загальну середню освіту [електронний ресурс] //: Закон України від 16.01.2020 № 463-IX (Редакція станом на 02.10.2021). - Режим доступу: https://zakon. навчального округу щодо відкриття 2-го шляхетного пансіону при 1-й Київській гімназії i проєкт його штату були надіслані міністру народної освіти і враховані при ухваленні остаточного рішення.

Перспективи подальших досліджень вбачаємо у вивченні досвіду діяльності ради при попечителі Харківського навчального округу щодо розв' язання проблеми відкриття та закриття приватних навчальних закладів та пансіонів.

rada.gov.ua/laws/show/463-20\#Text/ (дата звернення: 14.10.2021)

10. Прокопенко Л. Державне регулювання розвитку приватної освіти на Катеринославщині у першій половині XIX ст. / Л. Прокопенко // Аспекти публічного управління. - 2019. - Т. 7. - № 1-2. -С. 116-122

11. РГИА (Российский государственный исторический архив). - Ф. 733. - Оп. 69. Д. 303. С. 69 л.

12. Рождественский С. В. Исторический обзор деятельности Министерства народного просвещения: 1802-1902 / С. В. Рождественский. - Санкт-Петербург: Государственная типография. -, 1902. - С. 786 с.

13. Сборник постановлений по Министерству народного просвещения. Санкт-Петербург, 1875. - Т. 1. - Стб. 331-368

14. Сборник постановлений по Министерству народного просвещения. - СанктПетербург, 1875. - Т. 2. - Отд. 1. - Стб. 242

15. Сборник постановлений по Министерству народного просвещения. СанктПетербург, 1864. - Т. 1.- Стб. 13-21

\section{References:}

1. Honcharenko, S. (1997), "Ukrainian Pedagogical Dictionary”, Kyiv, p. 247

2. Honcharova, N. (2014), "Organizational principles of noble boarding schools functioning in the southern Ukrainian provinces in the first half of the nineteenth century", Naukovi zapysky Natsionalnoho universytetu "Ostrozka akademiia", series: Historical sciences, issue 22, pp. 88-97

3. Druhanova, O. (2018), "The Formation and Development of the Private Secondary School in Ukraine (The Late 18th and the First Half of the 19th Century)", Drynovskyi zbirnyk, Sofiia-Kharkiv, vol. 11, pp. 79-88

4. Journal of the Ministry of Public 
Education (1834), part 1, section I, pp. 53-59

5. Journal of the Ministry of Public Education (1835), part 6, section I, pp. 85-86, 90-91.

6. "Memo by Count Speransky "On the improvement of the people's general education" (1907), Russkaya starina, vol. 132, p. 731

7. Masliichuk, V. (2019), "Cultural and educational initiatives in the Left-bank and Sloboda Ukraine of the second half of the eighteenth - early nineteenth centuries", author's ref. dis. ... dr. of historical sciences, Zaporizhzhia, $34 \mathrm{p}$.

8. Cabinet of Ministers of Ukraine (2021), "On the affirmation of the Order of pupils residence and maintenance in boarding schools of educational institutions", available at: https://ww w.kmu.gov.ua/npas/pro-zatverdzhennya-poryad ku-prozhivannya-ta-utrimannya-uchniv-s113131121 (Accessed 04 November 2021)

9. Verkhovna Rada of Ukraine (2020), "About complete general secondary education", available at: https://zakon.rada.gov.ua/laws/show
1463-20\#Text/ (Accessed 14 October 2021)

10. Prokopenko, L. (2019), "State regulation of the development of private education in Katerynoslav region in the first half of the 19th century", Aspekty publichnoho upravlinnia, vol. 7, no. 1-2, pp. 116-122

11. RGIA (Russian State Historical Archive), fund 733, inventory 303, file 75, 69 sheets

12. Rozhdestvenskiy, S. (1902),

"Historical overview of the activities of the Ministry of Public Education: 1802-1902", St. Petersburg, p. 786 p.

13. Collection of Regulations of the Ministry of Public Education (1875), SanktPeterburg, vol. 1, ppcol. 331-368

14. Collection of Regulations of the Ministry of Public Education (1875), SanktPeterburg, vol. 2, section 1, ppcol. 242

15. Collection of Regulations of the Ministry of Public Education (1864), SanktPeterburg, vol. 1, ppcol. 13-21

Стаття надійшла до редколегії 20.11.2021 